\author{
Kuprina N. \\ Ph.D., Associate Professor \\ Department of Accounting and Auditing \\ E-mail:k.natali @ukr.net \\ Rudiuk I. \\ The student of the third grade of Economy, Business and Control Faculty \\ Odessa National Academy of Food Technologies \\ Kanatna str., 112, Odessa, Ukraine, 65039 \\ E-mail: ruduk2012@gmail.com
}

\title{
ANALYSIS OF APPROACHES TO ESSENCE AND CLASSIFICATION OF ACCOUNT RECEIVABLE OF ENTERPRISE
}

In the article the analysis of modern approaches has been conducted in relation to determination of essence of category "account receivable" and their classification with the aim of further realization of their effective administrative accounting and effective management of floating capital of enterprise. The research showed plenty of approaches of scientists both to determination of essence of account receivable and to its classification according to separate characteristics but this element of floating capital is very important nowadays because it has considerable specific gravity in structure and represents the distraction of turnover means from the capital of enterprise.

Keywords: account receivable, classification, assets, floating capital, management.

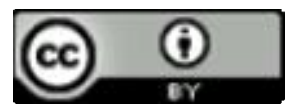

This work is licensed under a Creative Commons Attribution 4.0 International License http://creativecommons.org/licenses/by/4.0/
Statement of the problem and its connection with important scientific and practical tasks. Account receivable is inalienable part of economic activity of any enterprise. Rational management of it assists the increase of volumes of realization of products (commodities, works, services), expansion of sales market and, thus, increase of monetary resources, own turnover means. Enterprises try to increase the volumes of realization of products, however the volumes of account receivable grow as a result of it considerable part of floating capital is withdrawn from turnover, accordingly the level of solvency goes down and regular development of enterprise restrains.

The total amount of current account receivable of enterprises of Ukraine since 2010 has had the clearly expressed tendency to increase. The most part in composition of account receivable of current character is occupied by a debt between enterprises and establishments of Ukraine for commodities, works, services. So, to the end of 2012 the account receivable was $1701397,3 \mathrm{mln} \mathrm{UAH}$ that totaled $58,24 \%$ of circulating assets of enterprises of Ukraine by the types of economic activity, but in 2014 - 1962772,1 mln UAH and $59,99 \%$ and in 2015 - 2517203,5 mln UAH and 61,27\% accordingly and that is a negative tendency [1]. Such state of this element of floating capital of enterprise needs quality organization of its administrative accounting and permanent control.

The analysis of the latest publications on the problem. The problem of increase of account receivable and management methods found reflection in works of such scientists as: I. A. Blank, V.V. Babich, M.D. Bilyk, O. M. Boldyrev, N.I. Vlasyuk, S.F. Golova, E. V. Glushko, V. A. Yerofieieva, V.I.Yefymenko, O.V. Zymovets, S. V. Kobelieva, O. Y. Konov, G.O. Kramarenko, L. M. Kupriianova, L.V. Napadovska, N.Y. Nevmerzhitska, O.V.Pavlovska, N.M Prytulyak, S.V.Sagova, N. O. Smolyakova, O. V. Sergiienko, Y. S. Tsal Tsalko, L. V. Shkulypa and others, but they are relevant issues nowadays in time of functioning of enterprises of industry that needs additional research.

Forming of the aims of the research. The primary purpose of research is analysis of approaches in relation to determination of essence of category "account receivable of enterprise" and its classifications in modern terms from the theoretical and practical points of view as wellas consideration of methods of management of account receivable.

Giving an account of the main results and their substantiation. The modern stage of economic development of country is characterized by considerable deceleration of payment turnover that causes the increase of account receivable at enterprises that is why the important task of financial management is an effective management of an account receivable directed to optimization of its general size and providing of timely collection of debt [2, p. 592].

The large volume of account receivable of enterprises presents the debt of buyers (customers) for supplying of commodities, provision of services or 
implementation of work. Specific gravity of account receivable after calculation with buyers (customers) at its general to the sum totals as a rule $80-90 \%$ that is why management of an account receivable in a commercial organization is related first of all to optimization of size and providing the collection of debt of buyers (customers) after calculation for the realized products or provided services or performed works. In opinion of I. A. Blank for effective management of an account receivable at enterprises special financial policy of management of an account receivable or its credit policy in relation to the buyers of products, must be developed and performed it is impossible not to agree with his opinion which requires determination of its theoretical and practical aspects for organization of its effective accounting and control.

Approaches according to the results of the research to determination of essence of category "account receivable of enterprise" are shown in table 1.

Table 1

Determination of essence of category "account receivable of enterprise" *

\begin{tabular}{|c|c|}
\hline Author, source & Determination of essence \\
\hline $\begin{array}{l}\text { Regulations standard } \\
\text { of accounting } 10 \text { "account" } \\
\text { receivable,[3] }\end{array}$ & Sum of debt of debtors to the enterprise for the certain date. \\
\hline $\begin{array}{l}\text { Kupriianova L. M., } \\
\text { Boldyryev O. M., [4,p. 48] }\end{array}$ & $\begin{array}{l}\text { Sum of debts which belonged to organization and that arose up in the process of } \\
\text { economic mutual relations with legal or physical entities. }\end{array}$ \\
\hline $\begin{array}{l}\text { Glushko Y. V., } \\
\text { Sergiienko O. V., [ 5,p.263 ] }\end{array}$ & $\begin{array}{l}\text { It is money that exist as obligations and requirements of physical and legal entities } \\
\text { that are debtors of organization. }\end{array}$ \\
\hline Shkulypa L. V., [6] & $\begin{array}{l}\text { Money in the unfinished calculation or account receivable that presents the debt of } \\
\text { other enterprises, organizations and individuals to this enterprise. }\end{array}$ \\
\hline $\begin{array}{l}\text { Antonyuk O.P., Stupnytska T.M, } \\
\text { Kuprina N.M., [7, p. 192] }\end{array}$ & Debt of legal and physical entities to the enterprise for the certain date. \\
\hline $\begin{array}{l}\text { A. Yerofieieva, } \\
\text { N. O. Smoliakova, [18] }\end{array}$ & $\begin{array}{l}\text { Variety of debt obligations and it is determined by the presence of temporal break } \\
\text { between sale of commodity and / or provision of service and its payment, two } \\
\text { grounds are distinguished: the first is related to the grant of postponement (arranging } \\
\text { on the installment system) of payment for the shipped products to the customers, and } \\
\text { second - with arranging for advance payments by organization. }\end{array}$ \\
\hline $\begin{array}{l}\text { Grabska Y.I., } \\
\text { Morozova O.S., [9] }\end{array}$ & $\begin{array}{l}\text { It is formed for an enterprise-supplier at shipping of its product arising up as a result } \\
\text { of discrepancy of time of payment for the sold products (given works or executed } \\
\text { services) from moments of transition of right of ownership on them or as a result of } \\
\text { the unfinished calculation at mutual obligations. }\end{array}$ \\
\hline Tsal-Tsalko Y.S., [16, p. 198] & $\begin{array}{l}\text { Sum of debt to the enterprise if there is probability of receipt of future economic } \\
\text { benefits and its sum can be determined for certain. }\end{array}$ \\
\hline $\begin{array}{l}\text { Alikina A. D., } \\
\text { Kostina O. V., [10] }\end{array}$ & $\begin{array}{l}\text { It is a sum of debts that belong to the enterprise from physical or legal entities at } \\
\text { their mutual relations with each other. }\end{array}$ \\
\hline $\begin{array}{l}\text { Berdnykova L. F., } \\
\text { Odarych V. V., [11] }\end{array}$ & $\begin{array}{l}\text { A debt of other organizations, workers and physical entities for the shipped products, } \\
\text { accountable sums, received loans. }\end{array}$ \\
\hline Yefimova O. V. [12, p. 306] & Sums that must be received from clients for goods and services. \\
\hline Tarasenko N.V., [24, p. 200] & $\begin{array}{l}\text { Distraction of turnover means from activity of enterprise (debt of enterprises, } \\
\text { organizations, entities to this enterprise). It is as an interest-free loan to the } \\
\text { customers, certain method of investing of floating capital. }\end{array}$ \\
\hline $\begin{array}{l}\text { Shutko G. M., } \\
\text { Rahimova R. R., [13] }\end{array}$ & $\begin{array}{l}\text { It is a rather dynamic element of turnover means that it depends substantially on the } \\
\text { policy accepted in a company in relation to the customers of products. }\end{array}$ \\
\hline Kramarenko G.O., [17, p. 252] & $\begin{array}{l}\text { In the process of performing obligations there is a natural, objective process of } \\
\text { financially-economic activity of enterprise. }\end{array}$ \\
\hline $\begin{array}{l}\text { Kulykova N. V., } \\
\text { Kurbatova D. O., [14] }\end{array}$ & $\begin{array}{l}\text { Sum of debts belonged to the enterprise, firm, company from the side of other } \\
\text { enterprises, firms and also citizens that are their debtors. }\end{array}$ \\
\hline $\begin{array}{l}\text { Instruction about application of } \\
\text { Plan of accounts of accounting } \\
\text { at banks of Ukraine, [23] }\end{array}$ & $\begin{array}{l}\text { Sum of requirements of bank to the legal and physical entities for the certain date in } \\
\text { relation to the receipt of assets, services and others like that. }\end{array}$ \\
\hline Romanova K. O., [15] & $\begin{array}{l}\text { One of the varieties of assets of an organization such as fixed assets, inventories, } \\
\text { monetary resources. }\end{array}$ \\
\hline
\end{tabular}

* It is made by the authors on the basis of analysis of sources

Research showed that most authors determine account receivable as a sum of debt or sum of debts or money as obligations of physical and legal entities to the enterprise or refer to Regulations (standard) of accounting 
10 "account receivable" [3], but all researchers confirmed that it is a debt of enterprise and distraction of monetary resources from activity of enterprise. Unlike these researchers Romanov K. O. and Yefimova O. V. consider account receivable as sum of money capitals that must be received from clients for goods and services. On the other side Shutko G. M., Rahimova R.R. consider that it is a rather dynamic element of turnover means that it depends substantially on the policy accepted in a company in relation to the customers of products it is impossible not to agree with claim of that. Grabska Y.I., Morozova O.S. underline that an account receivable is formed for an enterprise-supplier at shipping of its product arising up as a result of discrepancy of time of payment for the sold products (given works or executed services) from moments of transition of right of ownership on them or as a result of the unfinished calculation within mutual obligations.

With the aim of realization of quality accounting and analysis of account receivable and management of it, it is necessary to define the signs of its classification and methodology of realization of its analysis and administrative accounting that is a further direction of the research. So, the important instrument of research of that allows to find out reasons of the origin of account receivable and also factors that influence its change, is a classification of account receivable that allows to make reasonable decisions in relation to the management of it. As research showed there is an enormous amount of variations of distribution of account receivable by different characteristics with the aim of systematization of information on its state, realization of analysis for making the optimal decisions in the process of management of it [2, 18 and others].

Approval of National regulations (standard) of accounting 1 "General requirements to the financial statement" [20] led to the distinguishing of principal and additional articles in form № 1 "Balance (Statement of financial state)" (table 2) and approaches to classification of account receivable which are represented in works of scientists shown in table 3 .

Table 2

Classification of account receivable in accordance with $\mathrm{N}(\mathrm{S}) \mathrm{A}$ and forms of the financial statement of enterprise*

\begin{tabular}{|c|c|c|}
\hline $\begin{array}{l}\text { Normative document, } \\
\text { source }\end{array}$ & Charactaristics & Classification \\
\hline \multirow[t]{2}{*}{$\begin{array}{l}\text { Addition } 1 \text { to National regu- } \\
\text { lations (standard) } 1 \\
\text { "General requirements to the } \\
\text { financial statement" [20] }\end{array}$} & By elements & $\begin{array}{l}\text { 1.Principal articles: } \\
\text { - account receivable for products, commodities, } \\
\text { works, services ; } \\
\text { - account receivable for accounts; } \\
\text { - other current account receivable. } \\
\text { 2. Additional articles: } \\
\text { - account receivable for accounts by given } \\
\text { advances; } \\
\text { - account receivable for accounts with budget; } \\
\text { - including income tax. }\end{array}$ \\
\hline & By terms of repayment. & $\begin{array}{l}\text { - long-term } \\
\text { - current. }\end{array}$ \\
\hline \multirow{3}{*}{$\begin{array}{l}\text { Regulations (standard) of } \\
\text { accounting } 10 \text { "Account" } \\
\text { receivable [3] }\end{array}$} & By terms of repayment. & $\begin{array}{l}\text { - long-term; } \\
\text { - short-term. }\end{array}$ \\
\hline & $\begin{array}{l}\text { Depending on determination } \\
\text { of cost of current account } \\
\text { receivable. }\end{array}$ & $\begin{array}{l}\text { - } \text { account receivable for primary cost; } \\
\text { - account receivable for net realization cost; } \\
\text { - } \text { reserve of doubtful debts. }\end{array}$ \\
\hline & By degree of repayment & $\begin{array}{l}\text { - account receivable on the certain date (actual); } \\
\text { - hopeless; } \\
\text { - reserve of doubtful debts. }\end{array}$ \\
\hline $\begin{array}{l}\text { Order about approval of } \\
\text { form of accounting № } 5 \\
\text { "Notes to the financial } \\
\text { statement" [21] }\end{array}$ & $\begin{array}{l}\text { By terms of repayment: } \\
\quad \text { - account receivable for } \\
\text { products, commodities, works, } \\
\text { services; } \\
\text { - other current account } \\
\text { receivable. }\end{array}$ & $\begin{array}{l}\text { - up to } 12 \text { months; } \\
\text { - from } 12 \text { to } 18 \text { months; } \\
\text { - from } 18 \text { to } 36 \text { months. }\end{array}$ \\
\hline
\end{tabular}

* It is made by the authors on the basis of analysis of sources [3, 20, 21] 
Table 3

Approaches to the classification of account receivable *

\begin{tabular}{|c|c|c|c|c|c|c|c|c|c|c|c|c|c|c|c|}
\hline \multirow[b]{2}{*}{ 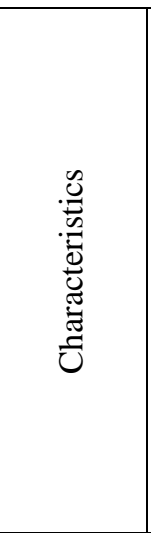 } & \multirow[b]{2}{*}{ Classification } & \multicolumn{14}{|c|}{ Author, source } \\
\hline & & 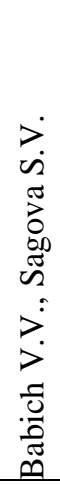 & 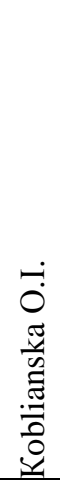 & 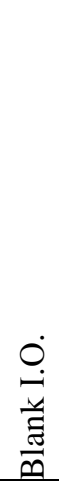 & $\begin{array}{l}\Sigma \\
\dot{\alpha} \\
\dot{0} \\
\dot{0} \\
0 \\
\dot{0}\end{array}$ & 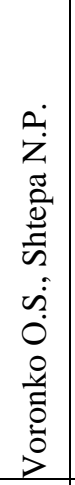 & 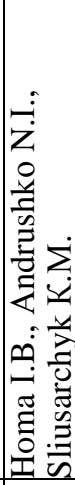 & 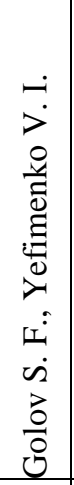 & 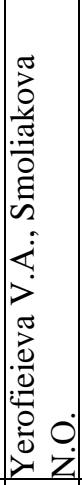 & 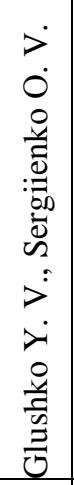 & 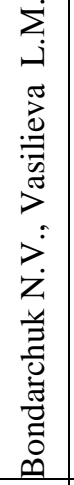 & 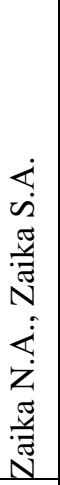 & 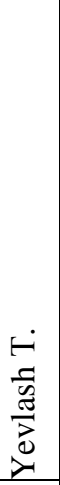 & 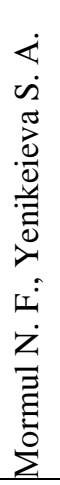 & 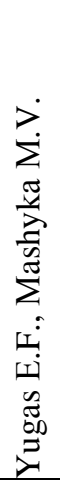 \\
\hline \multirow{11}{*}{ 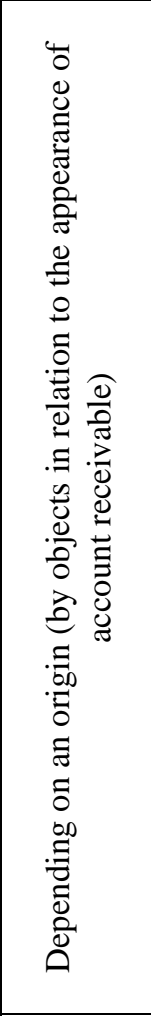 } & \multirow{3}{*}{$\begin{array}{l}\text { - account receivable for works, } \\
\text { commodities, services; or } \\
\text { - account receivable for } \\
\text { commodities, works, services, } \\
\text { which term of payment have not } \\
\text { come; or } \\
\text { - account receivable for works, } \\
\text { commodities, services being unpa- } \\
\text { id on time; }\end{array}$} & + & & & & & & & & & & + & & + & + \\
\hline & & & & + & & & & & & & & & & + & \\
\hline & & & & + & & & & & & & & & & & \\
\hline & $\begin{array}{l}\text { - debt of subsidiaries and } \\
\text { dependent societies }\end{array}$ & & & & & & & & & & & & & + & \\
\hline & $\begin{array}{l}- \text { account receivable for the re- } \\
\text { ceived bills of exchange; }\end{array}$ & + & & + & & & & + & & & & + & & & + \\
\hline & $\begin{array}{l}\text { - account receivable for calcu- } \\
\text { lation with budget; }\end{array}$ & + & & + & & & & & & & & & & & \\
\hline & $\begin{array}{l}\text { - debt of participants } \\
\text { (founders) for payments to charter } \\
\text { capital }\end{array}$ & & & & & & & & & & & & & + & \\
\hline & $\begin{array}{l}\text { - account receivable for calcu- } \\
\text { lation with staff; }\end{array}$ & & & + & & & & & & & & + & & & \\
\hline & $\begin{array}{l}\text { - account receivable of } \\
\text { leaseholder for financial lease }\end{array}$ & & & & & & & & & & & + & & & + \\
\hline & $\begin{array}{l}\text { - other types of account } \\
\text { receivable; }\end{array}$ & + & & + & & & & + & & & & + & & + & + \\
\hline & - receivables; & & & & & & & + & & & & & & & \\
\hline & - hopeless; & & + & & & + & + & & & + & & + & & + & \\
\hline$\hat{\theta} \hat{\infty} \frown$ & - doubtful; & & + & & & & + & & & + & + & + & & + & \\
\hline 苞节 & - actual; & & + & & & & & & & & & + & & + & \\
\hline 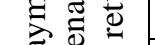 & - current; & & & & & & + & & + & + & + & + & & + & + \\
\hline$\approx \pi$ & - overdue; & & & & & + & & & + & + & & + & & + & \\
\hline$=0$ & - trade (operating); & & & & + & & & & & & & & & & \\
\hline$\dot{b}:=$ & - special (not operating); & & & & + & & & & & & & & & & \\
\hline है $\frac{0}{0}$. & - legal; & & & & & + & & & & & & & & & \\
\hline 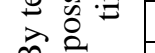 & - long-term; & & & & & & + & & & + & + & + & + & + & + \\
\hline & - short-term; & & & & & & & & & + & & & + & + & \\
\hline प्र & - mortgage; & & & & & & & & + & & & & & + & \\
\hline 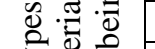 & - bank guarantee; & & & & & & & & + & & & & & + & \\
\hline$\sum \underset{\pi}{\frac{D}{\sigma}}$ & - bail; & & & & & & & & + & & & & & + & \\
\hline$\widehat{n}=\xi$ & - not provided; & & & & & & & & + & & & & & + & \\
\hline 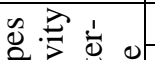 & - commercial & & & & & & & & & & & & & + & \\
\hline 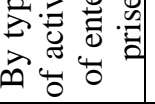 & - noncommercial & & & & & & & & & & & & & + & \\
\hline
\end{tabular}

*It is made by the authors on the basis of analysis of sources 
The analysis showed that most authors as Kobylianska O.I., Homa I.B., Andrushko N.I., Sliusarchyk K.M., Glushko Y. V., Sergiienko O. V., Bondarchuk N.V., Vasylieva L.M., Zaika N.A., Zaika S.A. classify debt by the term of repayment. In their works Voronko M., Voronko O.S., Shtepa N.P. in classification on the term of repayment pay attention: to the trade (operating), special (not operating) and legal account receivable. So, trade (operating) one arises up in the process of regular operating activity of enterprise as a result of selling commodities, implementation of works or provision of services for loan, special (not operating) one arises up as a result of overpayment of taxes, by percent to the receipt, by given advances and others like that [22]. Yerofieieva V.A. and Smoliakova N.O. classify an account receivable according to the types of material well-being that is characteristic for the account receivable at the credit drawing in bank institutions [18]. On the other side Mormul N. F. and Yenikeieva S. A. except classifications by the term of repayment and by the types of material well-being distinguish classification by the types of the activity of enterprise. So, the debt is considered commercial when it is conditioned by basic activity of enterprise, i.e. by a production and realization of products (works, services) : pre-pay and advances to the suppliers (i.e. crediting of purchases of raw material, materials, components etc.); a postponement of payment to the customers for the shipped products (commodity credits); overpayment for the commercial purchases (superfluous the enumerated money). The debt related to administratively economic activity of enterprise is considered noncommercial: overpayment on taxes and collections, social insurance and also debt on the salary of personnel; debt of founders for payments; advances given to the workers of enterprise for implementation of administrative functions; credits and loans given to the employees; advances for leasings payments [19].

Classification by elements with the aim of analysis and management of every element of account receivable is proved by $\mathrm{I}$. Blank that distinguishes such types of debt [2]: account receivable for commodities, works, services the terms of their payment did not come; account receivable for commodities, works, services unpaid in time; an account receivable on the received bills of exchange; an account receivable after calculation with a budget; an account receivable after calculation with a personnel; other types of account receivable. In opinion of I.Blank as well as of the most scientists among all enumerated types the most volume of account receivable of enterprise is the debt of customers for the shipped products (three first types of account receivable) with what it is impossible not to agree and it needs additional research. Therefore the analysis and management of account receivable must be concentrated exactly on it [2], that is why we have formed the approach to the classification of account receivable of enterprises of food industry with the aim of organization of their administrative accounting and realization of economic analysis.

Conclusions and prospects of the further investigations. As a result of this scientific research it is possible to do the following conclusions:

1. The analysis of works of national scientists in relation to essence of account receivable showed that there is an enormous amount of approaches in relation to determination of its essence but most authors refer exactly to Regulations (standard) of accounting 10 "account receivable" and all researchers confirmed that it is a debt of enterprise and distraction of monetary resources from activity of enterprise.

2. The analysis of works of national scientists in relation to classification of account receivable showed that there is an enormous amount of variations of distribution of account receivable by different characteristics with the aim of systematization of information on its state, realization of analysis for the making optimal decisions in the process of management of it and allowed us to form the approach to its classification for qualitative organization of administrative accounting and realization of its economic one on the enterprises of food industry.

3. For effective activity of enterprise management of such element of floating capital as an account receivable is necessary that substantially influences the financial state of enterprise, its solvency and liquidity of its assets and it needs additional research and analysis of its state on the enterprises of food industry.

\section{References}

1. Onyshchenko , S. V., \& Vereshchaka, T. P. (2016). Upravlinnia debitorskoiu zaborhovanistiu pidpryiemstv v umovakh kryzy neplatezhiv . Young Scientist, 12(39), 809-815.

2. Blank I.A. (1999). Osnovy finansovoho menedzhmenta. K. Nyka Tsentr.

3. Polozhennia (standart) bukhhalterskoho obliku 10 «Debitorska zaborhovanist» zatverdzhene nakazom Ministerstva finansiv 08.10.99 № 237 : za stanom na 27 chervnia 2016 r. Retrieved May 11, 2017, from https://buhgalter911.com/normativnaya-baza/instr-plan-rah/standart-buhgalterskogo/pologhennya-standartbuhgaltersykogo-1021475.html.

4. Kupriianov, L. M., \& Boldyriev, A. M. Otsinka efektyvnosti upravlinnia debitorskoiu zaborhovanistiu. Retrieved May 11, 2017, from http://cyberleninka.ru/article/n/otsenka-effektivnosti-upravleniya-debitorskoyzadolzhennostyu.

5. Hlushko, Ie. V. (2017). Teoretychni osnovy obliku debitorskoi zaborhovanosti. Molodyi vchenyi, 13, 263-268. 
6. Shkulypa, L. V. (2015). Zrostannia debitorskoi zaborhovanosti: perevahy ta nedoliky. Retrieved May 11 , 2017, from http://ekonomika.snauka.ru/2015/10/9891.

7. Antoniuk, O. P., Stupnytska, T. M., \& Kuprina, N. M. (2012). Ekonomichnyi analiz (praktykum). Lviv: Mahnoliia 2006.

8. Nakaz Pro prymitky do richnoi finansovoi zvitnosti zatverdzhenyi Ministerstvom finansiv Ukrainy vid 29.11.2000 №302. Retrieved May 11, 2017, from https://buhgalter911.com/blanki/finansovaya-otchetnost/forma-n-5prymitki/

9. Hrabska, Ia. I. Upravlinnia debitorskoiu zaborhovanistiu yak mekhanizm rozvytku ekonomichnykh vidnosyn v Rosii. Retrieved May 11, 2017, from http://naukovedenie.ru/PDF/37EVN516.pdf

10. Alikina, A. D., \& Kostina, O. V. Oblik debitorskoi zaborhovanosti. Retrieved May 11, 2017, from http://scientific-publication.com/h/sborniki/ekonomicheskie-nauki/289-uchet-debitorskoj-zadolzhennosti.html.

11. Berdnykova, L. F., \& Odarych, V. V. (2016). Sutnist i struktura debitorskoi ta kredytorskoi zaborhovanostei. Molodyi vchenyi, $9,5-8$.

OMEHA-L

12. Iefimova O.V. (2010). Finansovyi analiz: suchasnyi instrumentarii dlia pryiniattia ekonomichnykh rishen.

13. Shutko, H. M., \& Rakhimova, R. R. Upravlinnia debitorskoiu zaborhovanistiu pidpryiemstva. Retrieved April 3, 2017, from http://sci-article.ru/stat.php?i=1451314370.

14. Kulykova, N. V., \& Kurbatova, D. O. Upravlinnia debitorskoiu zaborhovanistiu v kryzu. Retrieved April 3, 2017, from http://e-koncept.ru/2016/96322.htm.

15. Romanova, K. O. Osnovni aspekty upravlinnia debitorskoiu zaborhovanistiu na pidpryiemstvakh APK. Retrieved April 3, 2017, from http://3minut.ru/stati-avtorov/570-osnovnye-aspekty-upravleniya.html.

16. Tsal-Tsalko Iu.S. (2008). Finansovyi analiz. K.TsUL.

17. Kramarenko H.O. (2008). Finansovyi analiz.TsUL.

18. Ierofieieva, V. A., \& Smoliakova, N. O. Systemnyi pidkhid do upravlinnia debitorskoiu zaborhovanistiu. Retrieved April 3, 2017, from http://www.upruchet.ru/articles/2011/2/5517.html.

19. Marmul , N. F., \& Yenikeieva, S. A. Rol klasyfikatsii v upravlinni debitorskoiu zaborhovanistiu . Retrieved April 3, 2017, from http://cyberleninka.ru/article/n/rol-klassifikatsii-v-upravlenii-debitorskoy-zadolzhennostyu.

20. Natsionalne polozhennia (standart) bukhhalterskoho obliku 1 «Zahalni vymohy do finansovoi zvitnosti» zatverdzhene nakazom Ministerstva finansiv 07.02.13 №73) : za stanom na 8 liutoho 2014 r. Retrieved April 3, 2017 , from https://buhgalter911.com/uk/normativnaya-baza/instr-plan-rah/standart-buhgalterskogo/nacionalyne-pologhennyastandartu-1021081.html.

21. Forma № 5 «Prymitky do richnoi finansovoi zvitnosti» (zatverdzheno nakazom Minfinu vid 29.11.2000 N 302 u redaktsii nakazu Minfinu vid 28.10.2003 N 602 iz zminamy vnesenymy nakazamy Minfinu N 989 vid 10.12.2002, N 602 vid 28.10.2003, N 1238 vid 14.10.2008. April 3, 2017, from https://buhgalter911.com/blanki/finansovaya-otchetnost/forma-n-5-prymitki/

22. Voronko R. M. (2009) Oblik u zarubizhnykh krainakh. L. «Mahnoliia 2006».

23. Instruktsiia pro zastosuvannia Planu rakhunkiv bukhhalterskoho obliku bankiv Ukrainy zatverdzhena postanovoiu Pravlinnia Natsionalnoho banku Ukrainy 17.06.2004 №280. Retrieved April 3, 2017, from http://zakon2.rada.gov.ua/laws/show/z0919-04

24. Tarasenko N.V. (2009). Finansovyi analiz. Lviv: «Novyi Svit-2000».

\section{Куприна Н.M.}

кандидат экономических наук, доцент кафрдра учёта и аудита E-mail: k.natali@ukr.net

Рудюк И.

Студент 3 курса фракультета экономики, бизнеса и контроля Одесская национальная академия пищевых технологий ул. Канатная, 112, г. Одеса, Украина, 65039 E-mail: ruduk2012@gmail.com

\section{АНАЛИЗ ПОДХОДОВ К СУЩНОСТИ И КЛАССИФИКАЦИИ ДЕБИТОРСКОЙ ЗАДОЛЖЕННОСТИ ПРЕДПРИЯТИЯ}

Основной целью исследования является анализ подходов по определению сущности категории «дебиторская задолженность предприятия» и ее классификации в современных условиях с тео 
ретической и практической точки зрения, а также методов управления дебиторской задолженностью.

В процессе исследования использовались методы: сравнительного анализа (для определения сущности категории «дебиторская задолженность предприятия» на основании анализа подходов ученых в научных публикациях) метод классификации (для анализа классификации дебиторской задолженности предприятия по отдельным признакам в нормативных документах по организации ее учета и отражения в финансовой отчетности и работах отечественных ученых для эффрективного управления нею).

Общая сумма текущей дебиторской задолженности предприятий Украины с 2010 г. по настоящее время имела четко выраженную тенденцию к росту, а наибольшую долю в составе текущей дебиторской задолженности занимает задолженность между предприятиями и учреждениями Украины за товары, работы, услуги. Такое состояние данного элемента оборотного капитала предприятия требует качественной организации ее управленческого учета и постоянного контроля. Анализ работ отечественных ученых о сущности дебиторской задолженности показал, что существует множество подходов к определению ее сущности, но большинство авторов ссылаются на П(С)БУ 10 «Дебиторская задолженность», и все исследователи подтвердили, что это задолженность предприятия и отвлечения денежных средств из деятельности предприятия. Анализ работ отечественных ученых о классификации дебиторской задолженности показал, что существует множество вариаций распределения дебиторской задолженности по различным признакам с целью систематизацииинформации о ее состоянии, проведения анализа для принятия оптимальных решений в процессе управления нею, что позволило нам сформировать подход по ее классификации для качественной организации управленческого учета и проведения ее экономического анализа на предприятиях пищевой промышленности. Для эффективной деятельности предприятия необходимо управление таким элементом оборотного капитала, как дебиторская задолженность, которая существенно влияет на фринансовое состояние предприятия, его платежеспособность и ликвидность его активов, что требует дополнительних исследований и анализа ее состояния на предприятиях пищевой промышленности.

Ключевые слова: дебиторская задолженность, классификация, активы, оборотный капитал, управление.

\author{
Купріна Н.M. \\ кандидат економічних наук, доцент \\ кафедра обліку та аудиту \\ E-mail: k.natali@ukr.net \\ Рудюк I. \\ Студент 3 курсу фракультету економіки, бізнесу і контролю \\ Одеська національна академія харчових технологій \\ вул. Канатна, 112, г. Одеса, Україна, 65039 \\ E-mail: ruduk2012@gmail.com
}

\title{
АНАЛІЗ ПІДХОДІВ ДО СУТНОСТІ ТА КЛАСИФІКАЦІЇ ДЕБІТОРСЬКОЇ ЗАБОРГОВАНОСТІ ПІДПРИЕМСТВА
}

Основною метою дослідження є аналіз підходів щодо визначення сутності категорії «дебіторська заборгованість підприємства» та її класифікації в сучасних умовах з теоретичного та практичного погляду, а також розгляду способів управління дебіторською заборгованістю. В процесі дослідження використовувались методи: порівняльного аналізу (для визначення сутності категорії «дебіторська заборгованість підприємства» на підставі аналізу підходів вчених в наукових працях); метод класифікації (для аналізу класифікації дебіторської заборгованості підприємства за окремими ознаками в нормативних документах щодо організації ії обліку та відображення у фінансової звітності та працях вітчизняних вчених для ефективного управління нею).

Загальна сума поточної дебіторської заборгованості підприємств України з 2010 р. по теперішній час мала чітко виражену тенденцію до зростання, а найбільшу частку в складі дебіторської заборгованості поточного характеру займає заборгованість між підприємствами та установами України за товари, роботи, послуги. Такий стан даного елементу оборотного капіталу підприємства потребує якісної організації ії управлінського обліку та постійного контролю. Аналіз праць вітчизнах науковців щодо сутності дебіторської заборгованості показав, що існує безліч підходів щодо визначення ії̈ сутності, але більшість авторів саме посилаються на П(С)БО 10 «Дебіторська заборгованість», та всі дослідники підтвердили, що це заборгованість підприємства та відволікання грошових коштів з діяльності підприємства. Аналіз праць вітчизняних науковців щодо класифікації дебіторської заборгованості показав, 
що існує безліч варіацій розподілу дебіторської заборгованості за різними ознаками з метою систематизування інформації щодо ії стану, проведення аналізу для прийняття оптимальних рішень у процесі управління нею та дозволів нам сформувати підхід до ії класифікації для якісної організації управлінського обліку та проведення її економічного на підприємствах харчової промисловості. Для ефективної діяльності підприємства необхідно управління таким елементом оборотного капіталу, як дебіторська заборгованість, яка суттєво впливає на фрінансовий стан підприємства, його платоспроможність та ліквідність його активів, що потребує додаткових досліджень та аналізу її стану на підприємствах харчової промисловості.

Ключові слова: дебіторська заборгованість, класифрікація, активи, оборотний капітал, управління.

\section{Література}

1. Онищенко С.В. Управління дебіторською заборгованістю підприємств в умовах кризи неплатежів / С.В. Онищенко, Т.П.Верещака // Young Scientist. - 2016. - № 12 (39). - С. 809-815.

2. Бланк І.А. Основи фінансового менеджмента / І.А. Бланк. - К. Ника Центр, 1999. - 592 с.

3. Положення (стандарт) бухгалтерського обліку 10 «Дебіторська заборгованість» затверджене наказом Міністерства фінансів 08.10.99 № 237 : за станом на 27 червня 2016 р. - [Електронний ресурс]. - Режим доступу до ресурсу: https://buhgalter911.com/normativnaya-baza/instr-plan-rah/standartbuhgalterskogo/pologhennya-standart-buhgaltersykogo-1021475.html.

4. Купріянов Л. М. Оцінка ефективності управління дебіторською заборгованістю [Електронний ресурс] / Л. М. Купріянов, А. М. Болдирєв // Світ нової економіки. - 2015. - №2. - С.47-55. - Режим доступу до pecypcy: http://cyberleninka.ru/article/n/otsenka-effektivnosti-upravleniya-debitorskoy-zadolzhennostyu.

5. Глушко Є. В. Теоретичні основи обліку дебіторської заборгованості / Є. В. Глушко, О. В. Сергієнко // Молодий вчений. - 2017. - №13. - С. 263-268.

6. Шкулипа Л.В. Зростання дебіторської заборгованості: переваги та недоліки [Електронний ресурс] / Л.В. Шкулипа - Режим доступу до ресурсу: http://ekonomika.snauka.ru/2015/10/9891.

7. Антонюк О.П. Економічний аналіз (практикум): [навч. посіб.] / О.П. Антонюк, Т.М. Ступницька, Н.М. Купріна. - Львів: «Магнолія 2006», 2012. - [2-ге видання, виправлене і доповнене]. - 326 с.

8. Наказ Про примітки до річної фінансової звітності затверджений Міністерством фінансів України від 29.11.2000 №302. - [Електронний ресурс]. - Режим доступу до ресурсу: https://buhgalter911.com/blanki/finansovaya-otchetnost/forma-n-5-prymitki/.

9. Грабська Я.І. Управління дебіторською заборгованістю як механізм розвитку економічних відносин в Росії [Електронний ресурс] / Я.І. Грабська. - Режим доступу до ресурсу: http://naukovedenie.ru/PDF/37EVN516.pdf.

10. Алікіна А. Д. Облік дебіторської заборгованості [Електронний ресурс] / А. Д. Алікіна, О. В. Костіна - Режим доступу до pecypcy: http://scientific-publication.com/h/sborniki/ekonomicheskie-nauki/289-uchetdebitorskoj-zadolzhennosti.html.

11. Бердникова Л. Ф. Сутність і структура дебіторської та кредиторської заборгованостей / Л. Ф. Бердникова, В. В. Одарич // Молодий вчений. - 2016. - №9. - С. 5-8.

12. Сфімова О.В. Фінансовий аналіз: сучасний інструментарій для прийняття економічних рішень / О.В. Єфімова // ОМЕГА-Л. - 2010. - С. 60-74.

13. Шутько Г. М. Управління дебіторською заборгованістю підприємства [Електронний ресурс] / Г. М. Шутько, Р. Р. Рахімова - Режим доступу до ресурсу: http://sci-article.ru/stat.php?i=1451314370.

14. Куликова Н. В. Управління дебіторською заборгованістю в кризу [Електронний ресурс] / Н. В. Куликова, Д. О. Курбатова // Науково-методичний електронний журнал «Концепт». - 2016. - №15. - С. 2016-2020. - Режим доступу до ресурсу: http://e-koncept.ru/2016/96322.htm.

15. Романова К. О. Основні аспекти управління дебіторською заборгованістю на підприємствах АПК [Електронний ресурс] / К.О. Романова - Режим доступу до ресурсу: http://3minut.ru/stati-avtorov/570-osnovnyeaspekty-upravleniya.html.

16. Цал-Цалко Ю.С. Фінансовий аналіз: [підруч.] / Ю.С. Цал-Цалко. - К.: ЦУЛ, 2008. - 566 с.

17. Крамаренко Г.О. Фінансовий аналіз: [підруч.] / Г.О. Крамаренко. - К:ЦУЛ, 2008. - 392 с.

18. Єрофєєва В.А. Системний підхід до управління дебіторською заборгованістю [Електронний ресурс] / В.А. Єрофєєва, Н.О. Смолякова - Режим доступу до ресурсу: http://www.upruchet.ru/articles/2011/2/5517.html.

19. Мармуль Н. Ф. Роль класифікації в управлінні дебіторською заборгованістю [Електронний ресурс] / Н. Ф. Мармуль, С. А. Снікеєва // Економічні і соціально-гуманітарні дослідження. - 2015. - № 4 (8). - С. $37-42$. - Режим доступу до ресурсу: http://cyberleninka.ru/article/n/rol-klassifikatsii-v-upravlenii-debitorskoyzadolzhennostyu.

20. Національне положення (стандарт) бухгалтерського обліку 1 «Загальні вимоги до фінансової звітності» затверджене наказом Міністерства фінансів 07.02.13 №73) : за станом на 8 лютого 2014 р. - [Електронний 
pecypc]. - Режим доступу до ресурсу: https://buhgalter911.com/uk/normativnaya-baza/instr-plan-rah/standartbuhgalterskogo/nacionalyne-pologhennya-standartu-1021081.html.

21. Форма № 5 «Примітки до річної фінансової звітності» (затверджено наказом Мінфіну від 29.11.2000 N 302 у редакції наказу Мінфіну від 28.10.2003 N 602 із змінами внесеними наказами Мінфіну N 989 від 10.12.2002, N 602 від 28.10.2003, N 1238 від 14.10.2008. - [Електронний ресурс]. - Режим доступу: https://buhgalter911.com/blanki/finansovaya-otchetnost/forma-n-5-prymitki/.

22. Воронко Р. М. Облік у зарубіжних країнах: [навч. посіб.] / Р.М. Воронко. - Л.: «Магнолія 2006», 2009. - 744 c.

23. Інструкція про застосування Плану рахунків бухгалтерського обліку банків України затверджена постановою Правління Національного банку України 17.06.2004 №280 [Електронний ресурс]. - Режим доступу до ресурсу: http://zakon2.rada.gov.ua/laws/show/z0919-04.

24. Тарасенко Н.В, Фінансовий аналіз: [навч. посіб.] / Н.В. Тарасенко. - Львів: «Новий Світ-2000», 2009. - 444 c.

Стаття надійшла 14.04.2017

Стаття прийнята до друку 28.04.2017

Доступно в мережі Internet 30.06.2017 